\title{
Impact of gender and androgen status on IGF-I levels in normal and GH-deficient adults
}

\author{
Sanne Fisker, Jens Otto L Jørgensen, Nina Vahl, Hans Ørskov ${ }^{1}$ and Jens Sandahl Christiansen \\ Medical Department M (Endocrinology and Diabetes) and ${ }^{1}$ Institute of Clinical Experimental Research, Aarhus University Hospital, Aarhus, Denmark \\ (Correspondence should be addressed to S Fisker, Medical Department M (Endocrinology and Diabetes), Aarhus Kommunehospital, Nørrebrogade 44, \\ DK-8000 Aarhus C, Denmark; Email: sf@afdm.aau.dk)
}

\begin{abstract}
Objective: The regulation of IGF-I levels is complex and not only dependent on GH status, as the diagnostic sensitivity of serum IGF-I levels for GH deficiency (GHD) in adults is low. Other GH-related parameters have so far not proven to be of additional diagnostic value in GHD adults. In the present study we evaluated the impact of gender and androgen status on IGF-I levels and the diagnostic value of IGF-I and GH-related parameters in a population of adult hypopituitary patients and age- and gender-matched healthy subjects.

Design: A cross-sectional study.

Subjects: Fifty-nine GHD patients (40 males, mean age $39.3 \pm 1.7$ (s.E.M.) years, and 19 females, mean age $41.9 \pm 2.6$ years) and 69 healthy subjects ( 42 males, mean age $36.7 \pm 1.5$ years, and 27 females, mean age $38.9 \pm 2.1$ years).

Results: IGF-I levels were low in the GHD patients (91 \pm 7 vs $173 \pm 7 \mu \mathrm{g} / \mathrm{l}, P<0.001)$, and lower in female patients than in male ( $68 \pm 10$ vs $100 \pm 8 \mu \mathrm{g} / \mathrm{l}, P=0.03)$. In the control group there was no gender-related difference in IGF-I levels (males: $178 \pm 8$, females: $164 \pm 12 \mu \mathrm{g} / \mathrm{l}, P=0.23$ ). IGF-II and IGF-binding protein-3 (IGFBP-3) were also decreased in GHD without any gender-related differences. GH-binding protein (GHBP) levels were increased in the patient group. The diagnostic sensitivity (\%) of IGF-I, IGF-I/GHBP, IGF-I/IGFBP-3, and of the combination of IGF-I plus IGF-II (both low or one normal and one low), was higher in female patients than in male (IGF-I: 57.8 vs 22.0, $P<0.0001$; IGF-I/GHBP: 84.2 vs $48.8, P=0.002$; IGF-I/IGFBP-3: 36.8 vs $7.3 P=0.001$; IGF-I + IGF-II: 77.8 vs 52.6, $P=0.01$ ). Testosterone levels were reduced in the female patients compared with female controls $(0.5 \pm 0.3$ vs $2.1 \pm 0.2 \mathrm{nmol} / \mathrm{l}, P<0.001)$. Forward regression analyses revealed that IGFBP-3 was a significant predictor of IGF-I levels in both patients and healthy subjects. In a combined analysis of both patients and controls, sex hormone-binding globulin (SHBG) level was the main contributor as an explanatory variable. Gender and prolactin also predicted IGF-I in patients, whereas SHBG and estradiol were significant predictors only in the control group.

Conclusion: (i) Levels of IGF-I, and of IGF-I/IGFBP-3 and IGF-I/GHBP ratios are lower in females compared with male adult GHD patients. (ii) IGF-I/GHBP has a high diagnostic sensitivity of adult GHD, in particular in women. (iii) We hypothesize that the gender difference in IGF-I levels among adult GHD patients are causally related to the very low androgen levels observed among females.
\end{abstract}

European Journal of Endocrinology 141 601-608

\section{Introduction}

The diagnosis of growth hormone (GH) deficiency (GHD) in adults with pituitary disease requires subnormal GH response to a stimulation test, preferably the insulin-tolerance test (ITT) (1). To obviate the need of laborious stimulation tests, single measurements of GH-dependent growth markers have been evaluated, of which insulin-like growth factor-I (IGF-I) has been shown to be of diagnostic value in children. It has, however, been demonstrated that IGF-I levels are of limited value in the diagnosis of adult GHD, since some patients with evidence of pituitary disease and pronounced GHD show IGF-I levels within the normal range (2-4). Serum IGF-binding protein-3 (IGFBP-3) levels, which have been shown to be useful in the diagnosis of childhood GHD (5), do not exhibit the same applicability in adults $(2,4)$. The IGF-I/IGFBP-3 ratio has been claimed to reflect free IGF-I, and thereby GH status (6); the diagnostic value of this ratio in adult GHD is not clarified. We have previously shown increased GH-binding protein (GHBP) levels in GHD patients, although with a marked overlapping with normal levels $(7,8)$. 
Table 1 Details of GHD patients and control subjects. (Means \pm S.E.M.).

\begin{tabular}{|c|c|c|c|c|c|c|c|c|}
\hline & \multicolumn{3}{|c|}{ Males } & \multicolumn{3}{|c|}{ Females } & \multicolumn{2}{|c|}{$\begin{array}{c}\text { Males vs females } \\
(P)\end{array}$} \\
\hline & GHD & Control & $P$ & GHD & Control & $P$ & GHD & Control \\
\hline$n$ & 40 & 41 & - & 19 & 27 & - & - & - \\
\hline Peak GH (Arg) $(\mu \mathrm{g} / \mathrm{l})$ & $\begin{array}{l}1.02 \pm 0.44 \\
(n=8)\end{array}$ & - & - & $\begin{array}{l}1.65 \pm 1.43 \\
(n=3)\end{array}$ & - & - & 0.090 & - \\
\hline Peak GH ITT $(\mu \mathrm{g} / \mathrm{l})$ & $\begin{array}{l}0.71 \pm 0.20 \\
(n=32)\end{array}$ & - & - & $\begin{array}{l}1.51 \pm 0.49 \\
(n=16)\end{array}$ & - & - & 0.683 & - \\
\hline $\mathrm{A} / \mathrm{C}^{*}$ & $33 / 7$ & - & - & $14 / 5$ & - & - & - & - \\
\hline Age (years) & $39.3 \pm 1.7$ & $36.7 \pm 1.5$ & 0.149 & $41.9 \pm 2.6$ & $38.9 \pm 2.1$ & 0.488 & 0.442 & 0.703 \\
\hline BMI $\left(\mathrm{kg} / \mathrm{m}^{2}\right)$ & $27.8 \pm 0.6$ & $24.3 \pm 0.5$ & $<0.001$ & $27.6 \pm 1.3$ & $23.5 \pm 0.6$ & 0.002 & 0.703 & 0.307 \\
\hline W/H & $0.94 \pm 0.01$ & $0.89 \pm 0.01$ & 0.001 & $0.88 \pm 0.02$ & $0.81 \pm 0.01$ & 0.002 & 0.003 & $<0.001$ \\
\hline
\end{tabular}

${ }^{*} \mathrm{~A} / \mathrm{C}$ : adulthood/childhood onset of GHD.

IGF-I levels are lower in female compared with male GHD patients (9), but the underlying mechanisms remain unknown $(10,11)$. So far it has not been thoroughly studied whether the diagnostic value of IGF-I and related factors could be improved by taking gender and sex steroid status into account.

We therefore evaluated the impact of gender and androgen status on IGF-I levels and related parameters in the GH-IGF axis in a group of GHD patients compared with reference data obtained from an age- and gender-matched control group.

\section{Subjects and methods}

The participants comprised 59 hypopituitary patients with GHD for at least 1 year and 68 age-matched healthy control subjects (Table 1). Apart from three female control subjects, who received estrogen supplementation, no one in the control group used any medication. Apart from patients with childhood-onset GHD none of the patients previously received long-term GH therapy. Additional hormonal substitution in the patients was sufficiently stabilized for at least 3 months prior to participating (Table 2). Estrogen replacement therapy of female patients contained $17 \beta$-estradiol preparations.

The diagnosis was ultimately based on a peak $\mathrm{GH}$ level less than $3 \mu \mathrm{g} / \mathrm{l}$ following either an ITT or an L-arginine stimulation test. ITT was performed by injection of a bolus of Actrapid (Novo Nordisk, Copenhagen, Denmark) in a dose of $0.075 \mathrm{IE} / \mathrm{kg}$ (0.05 IE/kg in patients substituted with corticosteroids). Arginine stimulation tests were performed by infusion of L-arginine $(0.5 \mathrm{~g} / \mathrm{kg}$, maximally $35 \mathrm{~g})$ during $30 \mathrm{~min}$. Peak GH levels are shown in Table 1.

Blood glucose was determined by the glucose oxidase method after stabilizing the sample in NaF until analysis. Serum GH was determined in an immunoflurometric assay (TR-IFMA, Delfia, Wallac, Finland), with two monoclonal antibodies directed against the
$22 \mathrm{kDa}$ variant of human GH. Serum IGF-I plus IGF-II analyses were performed with an in-house TR-IFMA after extraction of serum to remove binding proteins as previously described (12). Serum IGFBP-3 was measured by an RIA kit (Diagnostic Systems Laboratories Inc., Webster, TX, USA). Serum GHBP was determined in an in-house functional fluoro-immunoassay (7). Serum testosterone, sex hormone-binding globulin (SHBG), and estradiol were measured in immunofluorometric kits (Delfia). Serum prolactin was determined in a chemiluminescent enzyme immunoassay (Immulite; DPC, Los Angeles, CA, USA).

Anthropometric measures included body mass index (BMI) and waist/hip ratio $(\mathrm{W} / \mathrm{H})$.

\section{Statistical methods}

Parameters were compared between groups by Student's unpaired $t$-test when data were normally distributed, otherwise a Mann-Whitney test was performed. The Shapiro-Wilk test was performed to test for normality in the different groups, which all included less than 50 observations. The following parameters were not normally distributed in all groups: IGF-II, GHBP, IGF-I/GHBP, IGF-I+IGF-II, estradiol, testosterone,

Table 2 Hormone substitution in 59 GHD patients.

\begin{tabular}{lcl}
\hline Treatment & Males & Females \\
\hline None & $7(17.5 \%)$ & $6(31.6 \%)$ \\
T/E & $1(2.5 \%)$ & $2(10.5 \%)$ \\
$\mathrm{H}$ & $3(7.5 \%)$ & $1(5.3 \%)$ \\
$\mathrm{D}$ & $0(0 \%)$ & $1(5.3 \%)$ \\
$\mathrm{T} / \mathrm{E}+\mathrm{H}$ & $1(2.5 \%)$ & $2(10.5 \%)$ \\
$\mathrm{L}+\mathrm{H}$ & $1(2.5 \%)$ & $2(10.5 \%)$ \\
$\mathrm{T} / \mathrm{E}+\mathrm{L}+\mathrm{H}$ & $18(42.5 \%)$ & $3(15.8 \%)$ \\
T/E $+\mathrm{L}+\mathrm{H}+\mathrm{D}$ & $9(22.5 \%)$ & $2(10.5 \%)$
\end{tabular}

T/E: testosterone/estradiol; L: levothyroxine; H: hydrocortisone; D: desmopression. 
prolactin and SHBG. As differences between sensitivities (S)(in males and females) were normally distributed the difference was tested by the z-value calculated as $S_{\text {(males) }}-S_{\text {(females) }} / \sqrt{ }\left(S_{\text {(males) }}+S_{\text {(females) }}\right)$. Sensitivity was calculated as the number of adult GHD patients correctly identified by abnormal levels of IGF-related parameters and GHBP and using the cut-off levels defined by the 2.5 percentile derived from the control group relative to all patients (see Table 6). In stepwise linear regression analysis a $P$ value of 0.05 was used as the criterion for entry at each step. Correlation analyses were performed using Spearman's test as several parameters were not normally distributed. The statistic program SPSS 8.0 was used for all analyses.

\section{Results}

\section{Reference intervals (Table 3)}

From the group of healthy subjects the 2.5 percentiles (or the 97.5 percentiles) were obtained and used as cutoff levels to calculate the sensitivity of each parameter. All GH-IGF-related parameters were identical in male and female control subjects, for which reason the two data sets were pooled to obtain reference intervals.

\section{GH-related parameters (Table 3)}

As expected, mean values of IGF-I, IGF-II and IGFBP-3 were lower in patients compared with controls. In the control group, IGF-I levels were identical between sexes, whereas female GHD patients had lower IGF-I levels than their male counterparts. The ten female GHD patients who received hydrocortisone substitution had lower IGF-I levels than adrenocorticotropin-sufficient female patients $(n=9)(40 \pm 8$ (s.E.M.) vs $98 \pm 15 \mu \mathrm{g} / \mathrm{l}$, $P=0.003)$. Female patients with isolated GHD $(n=7)$ had significantly higher IGF-I levels than female patients treated with hydrocortisone and estrogen $(n=7) \quad(106 \pm 19$ vs $40 \pm 10 \mu \mathrm{g} / \mathrm{l}, \quad P=0.008)$, and higher levels than the rest of female patients $(n=12)$ $(106 \pm 19$ vs $45 \pm 7 \mu \mathrm{g} / \mathrm{l}, \quad P=0.003)$. IGF-I levels were not different in female patients with isolated GHD compared with female patients substituted with either estrogen alone or hydrocortisone alone (data not shown). Estrogen-treated female patients $(n=9)$ displayed lower levels of IGF-I compared with eugonadal female patients $(n=10)(46 \pm 9$ vs $90 \pm 18 \mu \mathrm{g} / \mathrm{l}$, $P=0.037$ ).

Serum levels of IGF-II and IGFBP-3 were identical in female and male patients, whereas the ratio IGF-I/ IGFBP-3 was significantly lower in female patients than in males.

\section{GHBP (Table 3)}

GHBP levels were significantly higher in GHD patients than in control subjects, but there were no genderdependent differences in either the control or patient group. The IGF-I/GHBP ratio was significantly lower in the patient group. Moreover this ratio was lower in female patients compared with male patients, whereas no gender difference was detected in the control group.

\section{Sex hormones and prolactin (Table 4)}

Testosterone levels were significantly reduced in the female patients compared with the female control subjects, whereas no differences between male patients and male controls were found. Not unexpectedly, testosterone levels were lower in female patients treated with hydrocortisone $(n=10) \quad(0.00 \pm 0.00 \mathrm{nmol} / \mathrm{l})$ compared with the rest of the female patients $(n=9)$ $(0.99 \pm 0.48 \mathrm{nmol} / \mathrm{l})(P=0.044)$.

Table 3 Ranges (mean \pm S.E.M.) and reference intervals (2.5-97.5 percentile) for different growth-related parameters. Males: $n=40$. Females: $n=19$. $P$ refers to comparison of means in males and females.

\begin{tabular}{|c|c|c|c|c|c|c|c|c|}
\hline \multirow[b]{2}{*}{ Parameter } & \multicolumn{3}{|c|}{ Control } & \multirow{2}{*}{$\begin{array}{l}\text { Reference interval } \\
\text { (females and males) }\end{array}$} & \multirow{2}{*}{$\begin{array}{c}\boldsymbol{P} \\
\text { (control vs GHD) }\end{array}$} & \multicolumn{3}{|c|}{ GHD } \\
\hline & Males & Females & $P$ & & & Males & Females & $P$ \\
\hline IGF-I $(\mu \mathrm{g} / \mathrm{I})$ & $\begin{array}{l}64-318 \\
(178 \pm 8)\end{array}$ & $\begin{array}{r}66-293 \\
(164 \pm 12)\end{array}$ & 0.23 & $\begin{array}{c}65-301 \\
(173 \pm 7)\end{array}$ & $<0.001$ & $100 \pm 8$ & $68 \pm 11$ & 0.03 \\
\hline IGF-II $(\mu \mathrm{g} / \mathrm{I})$ & $\begin{array}{c}724-2000 \\
(1034 \pm 43)\end{array}$ & $\begin{array}{c}749-1581 \\
(1089 \pm 48)\end{array}$ & 0.25 & $\begin{array}{l}726-1795 \\
(1055 \pm 32)\end{array}$ & $<0.001$ & $693 \pm 33$ & $681 \pm 70$ & 0.56 \\
\hline IGFBP-3 $(\mu \mathrm{g} / \mathrm{l})$ & $\begin{array}{c}1770-5041 \\
(2856 \pm 87)\end{array}$ & $\begin{array}{c}2046-3922 \\
(2836 \pm 88)\end{array}$ & 0.88 & $\begin{array}{r}1802-4201 \\
(3138 \pm 293)\end{array}$ & $<0.001$ & $2009 \pm 99$ & $1903 \pm 215$ & 0.30 \\
\hline GHBP (nmol/l) & $\begin{array}{c}0.53-3.57 \\
(1.24 \pm 0.12)\end{array}$ & $\begin{array}{c}0.50-2.12 \\
(1.10 \pm 0.08)\end{array}$ & 0.71 & $\begin{array}{c}1.04-3.05 \\
(1.18 \pm 0.07)\end{array}$ & $<0.001$ & $1.85 \pm 0.16$ & $1.93 \pm 0.13$ & 0.18 \\
\hline IGF-I/IGFBP-3 & $\begin{array}{c}0.03-0.12 \\
(0.064 \pm 0.03)\end{array}$ & $\begin{array}{c}0.03-0.11 \\
(0.055 \pm 0.001)\end{array}$ & 0.21 & $\begin{array}{c}0.031-0.116 \\
(0.060 \pm 0.003)\end{array}$ & $<0.001$ & $0.048 \pm 0.003$ & $0.034 \pm 0.004$ & 0.004 \\
\hline $\begin{array}{l}\text { IGF-I/GHBP } \\
(\mu \mathrm{g} / \mathrm{nmol})\end{array}$ & $\begin{array}{l}57.4-407.9 \\
(173 \pm 15)\end{array}$ & $\begin{array}{l}59.9-322.5 \\
(149 \pm 15)\end{array}$ & 0.78 & $\begin{array}{l}57.6-381.6 \\
(162 \pm 11)\end{array}$ & $<0.001$ & $69.0 \pm 8.4$ & $35.5 \pm 5.2$ & 0.01 \\
\hline
\end{tabular}


Table 4 Sex hormones and prolactin levels (means \pm S.E.M.) in GHD patients and control subjects.

\begin{tabular}{|c|c|c|c|c|c|c|c|c|}
\hline & \multicolumn{3}{|c|}{ GHD } & \multicolumn{3}{|c|}{ Control } & \multicolumn{2}{|c|}{$\begin{array}{l}\text { GHD vs control } \\
(P)\end{array}$} \\
\hline & Males & Females & $P$ & Males & Females & $P$ & Males & Females \\
\hline $\begin{array}{l}n \\
\text { Testosterone } \\
(\mathrm{nmol} / \mathrm{l})\end{array}$ & $\begin{array}{l}40 \\
26.6 \pm 2.2\end{array}$ & $\begin{array}{c}19 \\
0.5 \pm 0.3\end{array}$ & $<0.001$ & $\begin{array}{l}41 \\
23.0 \pm 0.9\end{array}$ & $\begin{array}{l}27 \\
2.1 \pm 0.2\end{array}$ & $<0.001$ & $\overline{0 .}$ & $\overline{0} .001$ \\
\hline $\begin{array}{l}\text { Estradiol } \\
(\mathrm{nmol} / \mathrm{l})\end{array}$ & $0.10 \pm 0.01$ & $0.13 \pm 0.03$ & 0.62 & $0.10 \pm 0.01$ & $0.21 \pm 0.03$ & 0.001 & 0.17 & 0.09 \\
\hline $\begin{array}{l}\text { SHBG } \\
(\mathrm{nmol} / \mathrm{l})\end{array}$ & $46.4 \pm 4.5$ & $77.0 \pm 9.0$ & 0.006 & $36.3 \pm 2.1$ & $54.9 \pm 3.3$ & $<0.001$ & 0.10 & 0.09 \\
\hline $\begin{array}{l}\text { Prolactin } \\
(\mathrm{ng} / \mathrm{ml})\end{array}$ & $12.4 \pm 1.7$ & $23.2 \pm 6.2$ & 0.14 & $12.4 \pm 1.7$ & $14.9 \pm 1.6$ & 0.14 & 0.39 & 1.00 \\
\hline Testosterone/SHBG & $0.59 \pm 0.10$ & $0.014 \pm 0.001$ & 0.001 & $0.69 \pm 0.20$ & $0.042 \pm 0.004$ & $<0.001$ & 0.05 & $<0.001$ \\
\hline
\end{tabular}

In the patient group, estradiol levels were identical between sexes owing to low estradiol levels among females. The difference between female patients and control subjects, did not, however, reach statistical significance. Clinically, all female patients receiving estrogen replacement therapy were sufficiently substituted. SHBG levels were lower in males than in females in both groups. The testosterone/SHBG ratio, which may be a surrogate estimate of free testosterone, was lower in females than in males. Moreover, this ratio was significantly lower in female patients compared with female controls, and it tended to be reduced in male patients compared with male controls $(P=0.05)$.

Table 5 Correlations between IGF-I and IGF-II, IGFBPs, GHBP, sex hormones, age and anthropometric features.

\begin{tabular}{|c|c|c|c|c|}
\hline \multirow[b]{3}{*}{ Parameter } & \multicolumn{4}{|c|}{ IGF-I } \\
\hline & \multicolumn{2}{|c|}{ GHD } & \multicolumn{2}{|c|}{ Control } \\
\hline & $r$ & $P$ & $r$ & $P$ \\
\hline $\begin{array}{l}\text { IGF-II } \\
\text { IGFBP-3 } \\
\text { GHBP } \\
\text { BMI }\end{array}$ & $\begin{array}{r}0.641 \\
0.709 \\
-0.089 \\
0.249\end{array}$ & $\begin{array}{c}<0.001 \\
<0.001 \\
0.51 \\
0.06\end{array}$ & $\begin{array}{r}-0.065 \\
0.255 \\
0.246 \\
0.024\end{array}$ & $\begin{array}{l}0.60 \\
0.04 \\
0.06 \\
0.85\end{array}$ \\
\hline $\begin{array}{r}\mathrm{W} / \mathrm{H}(\mathrm{M}) \\
(\mathrm{F})\end{array}$ & $\begin{array}{l}0.108 \\
0.061\end{array}$ & $\begin{array}{l}0.52 \\
0.83\end{array}$ & $\begin{array}{l}-0.135 \\
-0.210\end{array}$ & $\begin{array}{l}0.40 \\
0.31\end{array}$ \\
\hline Age & 0.038 & 0.78 & -0.265 & 0.03 \\
\hline Testosterone & $\begin{array}{r}-0.065 \\
0.571\end{array}$ & $\begin{array}{l}0.72 \\
0.02\end{array}$ & $\begin{array}{r}-0.021 \\
0.165\end{array}$ & $\begin{array}{l}0.90 \\
0.43\end{array}$ \\
\hline $\begin{array}{r}\text { Estradiol (M) } \\
\qquad(\mathrm{F})\end{array}$ & -0.118 & 0.42 & $\begin{array}{r}-0.161 \\
0.373\end{array}$ & $\begin{array}{l}0.31 \\
0.07\end{array}$ \\
\hline Prolactin & 0.354 & 0.007 & 0.117 & 0.35 \\
\hline $\begin{array}{r}\text { SHBG (M) } \\
(F)\end{array}$ & $\begin{array}{l}-0.544 \\
-0.644\end{array}$ & $\begin{array}{l}0.002 \\
0.007\end{array}$ & $\begin{array}{l}-0.224 \\
-0.145\end{array}$ & $\begin{array}{l}0.49 \\
0.43\end{array}$ \\
\hline $\begin{array}{r}\text { Testosterone/SHBG (M) } \\
\text { (F) }\end{array}$ & $\begin{array}{l}0.224 \\
0.561\end{array}$ & $\begin{array}{l}0.29 \\
0.02\end{array}$ & $\begin{array}{l}0.221 \\
0.206\end{array}$ & $\begin{array}{l}0.16 \\
0.32\end{array}$ \\
\hline
\end{tabular}

\section{Determinants of IGF-I}

Correlation coefficients for relations between IGF-I and other parameters are given in Table 5. For parameters which are different in males and females the genderspecific coefficients are given. In simple regression analyses IGF-I was correlated to IGF-II, IGFBP-3, prolactin and SHBG in the GHD patients, but only to IGFBP-3 in the control group. Age was also significantly correlated to IGF-I in the control group. Estradiol levels were not correlated to IGF-I, whereas a positive correlation between testosterone and IGF-I was recorded in female patients. In the group of female patients, who did not receive hydrocortisone therapy $(n=9)$, IGF-I was, however, not correlated to testosterone levels. We observed identical IGF-I levels in testosterone-substituted $(n=29)$ compared with eugonadal male patients $(n=11)$ (95 \pm 9 vs $108 \pm 18 \mu \mathrm{g} / \mathrm{l}, \mathrm{P}=0.51$ ).

In the prediction of IGF-I, forward stepwise regression analyses revealed that IGFBP-3, gender and prolactin were included as significant predictors in the final model in the patients, with IGFBP-3 being the main contributor. These three variables explained $67 \%\left(r^{2}\right)$ of the variability in IGF-I levels. In the control group IGF-I was poorly predicted by any of the potential determinants. Combining the two groups by introducing patient/control as a so-called dummy variable, IGFBP-3, patient/control, SHBG and estradiol became significant predictors accounting for $61 \%$ of IGF-I variation.

\section{Sensitivity (Table 6 and Fig. 1)}

Patients by definition were GH-deficient when peak GH to ITT or L-arginine was less than $3 \mu \mathrm{g} / \mathrm{l}$ (1). ITTs were performed in $80 \%$ of the male patients and in $84 \%$ of the female (Table 1). The diagnostic sensitivity of IGF-I, IGF-II, IGFBP-3 and IGF-I/IGFBP-3 were below $50 \%$, whereas IGF-I/GHBP and the combination of IGF-I plus IGF-II (both low or one normal and one low) 
Table 6 Sensitivity for different growth-related parameters. Males: $n=40$. Females: $n=19$.

\begin{tabular}{lrccc}
\hline & \multicolumn{3}{c}{ Sensitivity (\%) } & \\
\cline { 2 - 4 } Parameter & All & Males & Females & $P$ \\
\hline IGF-I & 33.9 & 22.0 & 57.8 & $<0.00004$ \\
IGF-II & 49.2 & 46.3 & 52.6 & 0.31 \\
IGFBP-3 & 47.5 & 41.5 & 57.9 & 0.06 \\
GHBP & 2.1 & - & - & - \\
IGF-I/IGFBP-3 & 22.0 & 7.3 & 36.8 & 0.001 \\
IGF-I/GHBP & 61.0 & 48.8 & 84.2 & 0.002 \\
IGF-I+ IGF-II* & 60.7 & 52.6 & 77.8 & 0.01 \\
\hline
\end{tabular}

* Low levels of IGF-I and/or low levels of IGF-II.

reached a sensitivity of $61 \%$. IGF-I levels were lower in female patients than in male patients $(68 \pm 11$ vs $100 \pm 8 \mu \mathrm{g} / \mathrm{l}, P=0.03)$, resulting in higher sensitivities of IGF-I and of the IGF-I-derived ratios, IGF-I/IGFBP-3 and IGF-I/GHBP in female patients. The combination of IGF-I plus IGF-II also exhibited higher diagnostic sensitivity in female patients. The gender-specific sensitivities were not changed significantly if related to gender-related normal ranges (data not shown). GHBP levels were significantly higher in the patients $(1.88 \pm$ 0.12 vs $1.18 \pm 0.07 \mathrm{nmol} / \mathrm{l}, P<0.001)$. However, only 3 of 59 patients had GHBP levels higher than the 97.5 percentile.

\section{Discussion}

Our study (i) confirms low sensitivity of IGF-I in the diagnosis of adult GHD, and low levels of IGF-I in female GHD patients compared with male patients; (ii) accordingly demonstrates a higher diagnostic sensitivity of IGF-I-related parameters in female than in male patients; and (iii) introduces the IGF-I/GHBP ratio as a potential diagnostic parameter in the diagnosis of adult GHD.

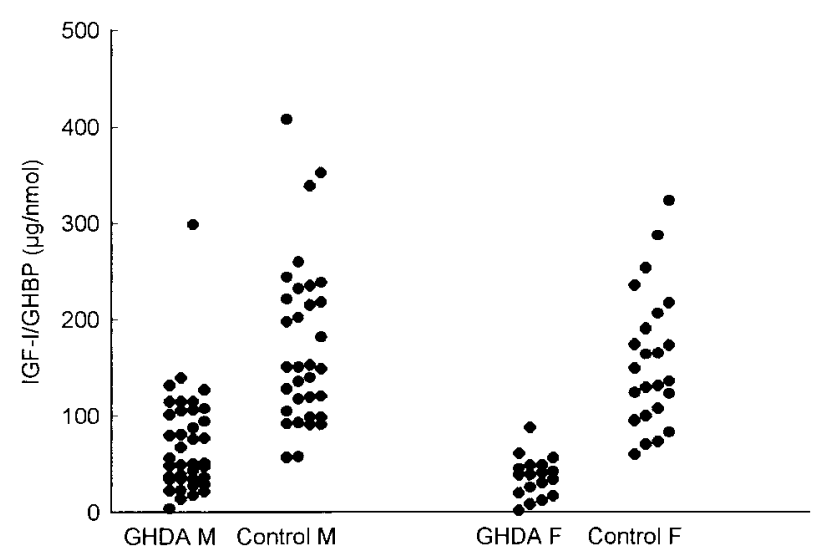

Figure 1 The IGF-I/GHBP ratio in male adult GHDA M patients, age-matched male control subjects, female adult GHDA F patients and age-matched female control subjects.
In children, IGF-I levels are comparable in prepubertal boys and girls (13). During puberty, however, IGF-I levels are higher in girls than in boys, even when corrected for Tanner stages (13). In young adults, IGF-I levels are higher in females, but in mid-life adult men display higher IGF-I levels $(10,14)$. These differences are believed mainly to depend on the GH status, which subsequently may be influenced by sex hormones. In agreement with this hypothesis, it has been demonstrated that IGF-I levels change during the menstrual cycle in healthy young females (15). It has also been shown that GH status in healthy mid-life adults is a rather weak predictor of serum IGF-I levels (10), and the observation of normal IGF-I levels in some hypopituitary adults with overt GHD clearly suggests that circulating IGF-I also depends on non-GH-related factors.

As expected, testosterone levels were low in our female patients, which reflects hypogonadism, in addition to blunted adrenal androgen production. Young et al. (16) demonstrated that panhypopituitary patients had undetectable levels of dehydroepiandrosterone (DHEA) and DHEA-sulfate, which are co-secreted and subsequently converted to testosterone in peripheral tissues. It is tempting to relate the subnormal testosterone levels to the relatively low IGF-I levels and reduced responsiveness to $\mathrm{GH}$ therapy observed in female hypopituitary patients. It could be suggested that a certain threshold level of androgens is necessary and plays a permissive role for IGF-I stimulation by GH and factors not related to the GH-IGF-I axis. This hypothesis is supported by our observation that IGF-I correlated positively to both testosterone and testosterone/SHBG in female patients. To pursue this hypothesis it would be informative to evaluate the effects of low-dose androgen substitution on IGF-I levels in hypopituitary female patients. Two recent studies have demonstrated that female GHD patients respond less to $\mathrm{GH}$ replacement therapy than do males with respect to IGF-I generation and changes in body composition $(9,17)$. In the study by Burman et al. (9) it was also reported that female patients had lower IGF-I levels at baseline than men. The IGF-I levels in that study were comparable with those of the present study.

It has previously been established that exogenous estrogen lowers IGF-I levels in postmenopausal women. Weissberger et al. (18) hypothesized this effect to be the result of a direct hepatic effect of estrogen, since only orally administered estrogen lowered IGF-I levels. Other groups have, however, found that the estrogen effect on IGF-I levels was not route specific $(19,20)$. In accordance with these studies, we found estrogen-substituted GHD females to have lower IGF-I levels compared with the rest of the group. We did, however, also observe lower IGF-I levels in females receiving hydrocortisone, and among female patients testosterone, but not estradiol, correlated significantly to IGF-I. As mentioned, we favor the interpretation of a permissive effect of 
testosterone on IGF-I production. It is also noteworthy that endogenous estradiol appears to stimulate IGF-I production via GH (15), which may suggest that the suppressive effect of exogenous estradiol on IGF-I levels is secondary to concomitant lowering of androgen production.

The regulation of SHBG levels seems to be inversely correlated to the activity of the GH-IGF axis, since low SHBG levels are observed during puberty concomitant with an increase in GH and IGF-I $(21,22)$. Furthermore, SHBG levels are increased in GHD children and decrease during $\mathrm{GH}$ replacement therapy (22). It has previously been demonstrated that IGF-I levels correlate inversely to SHBG $(10,11)$ in GHD patients and in elderly healthy subjects. Our data are in line with these findings as SHBG correlated negatively to IGF-I levels in patients, although not in healthy subjects in simple correlation analyses. In regression analyses SHBG was a common negative determinant of IGF-I levels although not present in the patient group, where gender replaced SHBG as a significant determinant. We also found that GHD patients had higher levels of SHBG compared with age-matched controls, and SHBG levels were higher in females in both groups. The mechanism by which SHBG negatively influences IGF-I levels is unclear, but the most plausible explanation is that SHBG levels are regulated by sex hormones, which influence IGF-I levels.

Hyperprolactinemia has previously been suggested to increase IGF-I levels in GHD patients with prolactinomas or with craniopharyngeomas $(23,24)$. We found that prolactin was a significant determinant of IGF-I levels in the GHD patients, and it is therefore possible that subtle hyperprolactinemia, which is a common occurrence in hypopituitary patients, may partly account for the spuriously normal IGF-I levels detected in a proportion of these patients. In normal subjects, however, prolactin does not seem to be a significant determinant of IGF-I.

As expected, the patients had higher BMIs and higher $\mathrm{W} / \mathrm{H}$ ratios than the control subjects. Levels of IGF-I are known to depend on body fat. We found, however, no correlation of IGF-I to either BMI or $\mathrm{W} / \mathrm{H}$ in any of the groups.

GHBP is produced from proteolytical cleavage of the $\mathrm{GH}$ receptor $(25,26)$. Recent studies have, however, suggested that the circulating binding protein is also cleaved from a truncated receptor lacking 97.5\% of the intracellular part, which is a result of an alternatively spliced mRNA $(27,28)$. High levels of GHBP have been found in conditions with low GH levels, including simple obesity $(7,29)$ and vice versa in, for example, acromegaly and insulin-dependent diabetes mellitus (7, 30-33). These data suggest that the $\mathrm{GH}$ receptor in some way is up-regulated in GH-insufficient conditions. By this means GHBP and IGF-I may represent two distinct and independent markers of $\mathrm{GH}$ status, which may explain why the ratio of IGF-I to GHBP provides increased diagnostic sensitivity over each parameter alone.

In GHD children it has been demonstrated that only a minor fraction exhibit normal levels of both IGF-I plus IGF-II (34), which results in a high sensitivity of the test 'low IGF-I and/or IGF-II low'. The statistical consequence, however, is that the specificity of this test is decreased compared with those of the single parameters. We also found a high diagnostic sensitivity of the combination of IGF-I plus IGF-II in adults. As a result of decreased IGF-I levels in females compared with male patients the analysis exhibited higher sensitivity in females.

The ratio IGF-I/IGFBP-3 increases during GH treatment (35), and it is high in acromegaly (6). Furthermore, we have previously found that the molar ratio of IGF-I to IGFBP-3 was decreased in adult GHD patients (10). Accordingly, we also found decreased levels in the GHD patients in the present study, but the ratio was of no diagnostic value due to overlapping with normal levels.

In summary, our data extend the observation that the regulation of serum IGF-I levels in adults is complex and not only dependent on GH status. The overlap in IGF-I levels between normal and adult GHD patients is mainly prevalent among males, and it is suggested that measurements of IGF-I-related parameters could be of diagnostic value in female patients. Finally, we suggest a causal relationship between low levels of androgens and IGF-I in female hypopituitary patients which merits further investigation.

\section{Acknowledgements}

SF was supported by a research fellowship from the University of Aarhus. The study was supported by the Danish Health Research Council, grant no. 9600822 (Aarhus University-Novo Nordisk Center for Research in Growth and Regeneration).

\section{References}

1 Participants in the Growth Hormone Research Society Workshop on Adult Growth Hormone Deficiency. Consensus guidelines for the diagnosis and treatment of adults with growth hormone deficiency: summary statement of the Growth Hormone Research Society Workshop on adult growth hormone deficiency. Journal of Clinical Endocrinology and Metabolism 199883 379-381.

2 Hoffman DM, O'Sullivan AJ, Baxter RC \& Ho KK. Diagnosis of growth-hormone deficiency in adults. Lancet 1994343 1064-1068.

3 Bates AS, Evans AJ, Jones P \& Clayton RN. Assessment of GH status in adults with GH deficiency using serum growth hormone, serum insulin-like growth factor-I and urinary growth hormone excretion. Clinical Endocrinology 199542 425-430.

4 Baum HB, Biller BM, Katznelson L, Oppenheim DS, Clemmons DR, Cannistraro $\mathrm{KB}$ et al. Assessment of growth hormone (GH) secretion in men with adult-onset GH deficiency compared with that in normal men - a clinical research center study. Journal of Clinical Endocrinology and Metabolism 199681 84-92. 
5 Smith WJ, Nam TJ, Underwood LE, Busby WH, Celnicker A \& Clemmons DR. Use of insulin-like growth factor-binding protein-2 (IGFBP-2), IGFBP-3, and IGF-I for assessing growth hormone status in short children. Journal of Clinical Endocrinology and Metabolism 199377 1294-1299.

6 Juul A, Main K, Blum WF, Lindholm J, Ranke MB \& Skakkebæk NE. The ratio between serum levels of insulinlike growth factor (IGF)-I and the IGF binding proteins (IGFBP-1, 2 and 3) decreases with age in healthy adults and is increased in acromegalic patients. Clinical Endocrinology 199441 85-93.

7 Fisker S, Frystyk J, Skriver L, Vestbo E, Ho KKY \& Ørskov H. A simple, rapid immunometric assay for determination of functional and growth hormone (GH)-occupied $\mathrm{GH}$-binding protein in human serum. European Journal of Clinical Investigation 199626 $779-785$.

8 Fisker S, Vahl N, Hansen TB, Jørgensen JOL, Hagen C, Ørskov H et al. Growth hormone (GH) substitution for one year normalises elevated GH-binding protein levels in GH-deficient adults secondary to a reduction in body fat. A placebo-controlled trial. Growth Hormone and Insulin-Like Growth Research 19988 105-112.

9 Burman P, Johansson AG, Siegbahn A, Vessby B \& Karlsson FA. Growth hormone (GH)-deficient men are more responsive to $\mathrm{GH}$ replacement therapy than women. Journal of Clinical Endocrinology and Metabolism 199782 550-555.

10 Jørgensen JOL, Vahl N, Hansen TB, Skjærbæk C, Fisker S, Ørskov H et al. Determinants of serum insulin-like growth factor I in growth hormone deficient adults as compared with healthy subjects. Clinical Endocrinology 199848 479-486.

11 Pfeilschifter J, Scheidt Nave C, Leidig Bruckner G, Woitge HW, Blum WF, Wuster $\mathrm{C}$ et al. Relationship between circulating insulin-like growth factor components and sex hormones in a population-based sample of 50- to 80-year-old men and women. Journal of Clinical Endocrinology and Metabolism 1996 $812534-2540$.

12 Frystyk J, Dinesen B \& Ørskov H. Non-competitive time-resolved immunofluorometric assays for determination of human insulin-like growth factor I and II. Growth Regulation 19955 169-176.

13 Juul A, Bang P, Hertel NT, Main K, Dalgaard P, Jørgensen K et al. Serum insulin-like growth factor-I in 1030 healthy children adolescents, and adults: relation to age, sex, stage of puberty, testicular size, and body mass index. Journal of Clinical Endocrinology and Metabolism 199478 744-752.

14 Landin Wilhelmsen K, Wilhelmsen L, Lappas G, Rosen T, Lindstedt G, Lundberg PA et al. Serum insulin-like growth factor I in a random population sample of men and women: relation to age, sex, smoking habits, coffee consumption and physical activity, blood pressure and concentrations of plasma lipids, fibrinogen, parathyroid hormone and osteocalcin. Clinical Endocrinology $199441351-357$.

15 Ovesen P, Møller J, Møller N, Christiansen JS, Ørskov H \& Jørgensen JO. Growth hormone secretory capacity and serum insulin-like growth factor I levels in primary infertile, anovulatory women with regular menses. Fertility and Sterility 199257 97-101.

16 Young J, Couzinet B, Nahoul K, Brailly S, Chanson P, Baulieu EE et al. Panhypopituitarism as a model to study the metabolism of dehydroepiandrosterone (DHEA) in humans. Journal of Clinical Endocrinology and Metabolism 199782 2578-2585.

17 Johannsson G, Bjarnason R, Bramnert M, Carlsson LMS, Degerblad M, Manhem $\mathrm{P}$ et al. The individual responsiveness to growth hormone $(\mathrm{GH})$ treatment in $\mathrm{GH}$-deficient adults is dependent on the level of GH-binding protein, body mass index, age, and gender. Journal of Clinical Endocrinology and Metabolism 199681 1575-1581.

18 Weissberger AJ, Ho KK \& Lazarus L. Contrasting effects of oral and transdermal routes of estrogen replacement therapy on 24-h growth hormone $(\mathrm{GH})$ secretion, insulin-like growth factor I, and
GH-binding protein in postmenopausal women. Journal of Clinical Endocrinology and Metabolism 199172 374-381.

19 Friend KE, Hartman ML, Pezzoli SS, Clasey JL \& Thorner MO. Both oral and transdermal estrogen increase growth hormone release in postmenopausal women - a clinical research center study. Journal of Clinical Endocrinology and Metabolism 199681 2250-2256.

20 Gravholt CG, Naeraa RW, Fisker S \& Christiansen JS. Body composition and physical fitness are major determinants of the growth hormone-insulin-like growth factor axis aberrations in adult Turner's syndrome, with important modulations by treatment with $17 \beta$-estradiol. Journal of Clinical Endocrinology and Metabolism 199782 2570-2577.

21 Apter D, Bolton NJ, Hammond GL \& Vihko R. Serum sex hormone-binding globulin during puberty in girls and in different types of adolescent menstrual cycles. Acta Endocrinologica $1984107413-419$.

22 Belgorosky A \& Rivarola MA. Progressive decrease in serum sex hormone-binding globulin from infancy to late prepuberty in boys. Journal of Clinical Endocrinology and Metabolism 198663 510-512.

23 Clemmons DR, Underwood LE, Ridgway EC, Kliman B \& Van Wyk JJ. Hyperprolactinemia is associated with increased immunoreactive somatomedin $\mathrm{C}$ in hypopituitarism. Journal of Clinical Endocrinology and Metabolism 198152 731-735.

24 Bucher H, Zapf J, Torresani T, Prader A, Froesch ER \& Illig R. Insulin-like growth factors I and II, prolactin, and insulin in 19 growth hormone-deficient children with excessive, normal, or decreased longitudinal growth after operation for craniopharyngioma. New England Journal of Medicine 1983309 1142-1146.

25 Sotiropoulos A, Goujon L, Simonin G, Kelly PA, Postel Vinay MC \& Finidori J. Evidence for generation of the growth hormonebinding protein through proteolysis of the growth hormone membrane receptor. Endocrinology 1993132 1863-1865.

26 Leung DW, Spencer SA, Cachianes G, Hammonds RG, Collins C, Henzel WJ et al. Growth hormone receptor and serum binding protein: purification, cloning and expression. Nature 1987330 537-543.

27 Dastot F, Sobrier ML, Duquesnoy P, Duriez B, Goossens M \& Amselem S. Alternatively spliced forms in the cytoplasmic domain of the human growth hormone $(\mathrm{GH})$ receptor regulate its ability to generate a soluble GH-binding protein. Proceedings of the National Academy of Sciences of the USA 199693 10723-10728.

28 Amit T, Bergman T, Dastot F, Youdim MB, Amselem S \& Hochberg Z. A membrane-fixed, truncated isoform of the human growth hormone receptor. Journal of Clinical Endocrinology and Metabolism 199782 3813-3817.

29 Jørgensen JO, Pedersen SB, Børglum J, Frystyk J, Ho KK, Christiansen JS et al. Serum concentrations of insulin-like growth factors (IGFs), IGF binding proteins 1 and 3 and growth hormone binding protein in obese women and the effects of growth hormone administration: a double-blind, placebocontrolled study. European Journal of Endocrinology 1995133 65-70.

30 Roelen CA, Donker GH, Thijssen JH, Koppeschaar HP \& Blankenstein MA. High affinity growth hormone binding protein in plasma of patients with acromegaly and the effect of octreotide treatment. Clinical Endocrinology 199237 373378 .

31 Kratzsch J, Blum WF, Ventz M, Selisko T, Birkenmeyer G \& Keller E. Growth hormone-binding protein-related immunoreactivity in the serum of patients with acromegaly is regulated inversely by growth hormone concentration. European Journal of Endocrinology $1995132306-312$.

32 Mercado M, Molitch ME \& Baumann G. Low plasma growth hormone binding protein in IDDM. Diabetes 199241 605-609.

33 Menon RK, Arslanian S, May B, Cutfield WS \& Sperling MA. Diminished growth hormone-binding protein in children with 
insulin-dependent diabetes mellitus. Journal of Clinical Endocrinology and Metabolism 199274 934-938.

34 Rosenfeld RG, Wilson DM, Lee PD \& Hintz RL. Insulin-like growth factors I and II in evaluation of growth retardation. Journal of Pediatrics $1986109428-433$.

35 Van-Teunenbroek A, de-Muinck-Keizer S, Stijnen T, Waelkens J, Wit JM, Vulsma T et al. Growth response and levels of growth factors after two years growth hormone treatment are similar for a once and twice daily injection regimen in girls with Turner syndrome. Clinical Endocrinology 199746 451-459.
Received 1 March 1999

Accepted 18 August 1999 